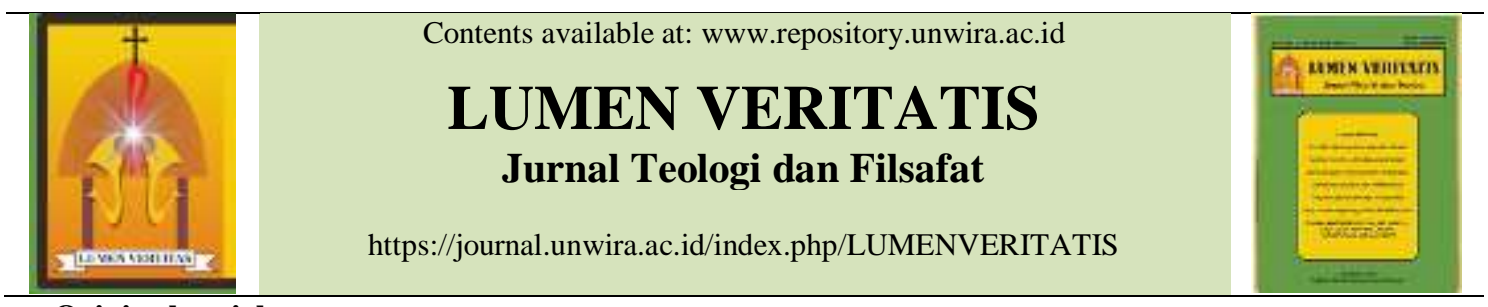

Original article

doi: 10.30822/lumenveritatis.v10i1.208

\title{
KUPU-KUPU DI ATAS BUNGA - ANGIN MENARI MELALUI PADANG: MENYIMAK FILSAFAT SENI MARTIN HEIDEGGER
}

\author{
Yasintus T. Runesi \\ Program Studi Ilmu Filsafat, Fakultas Filsafat, Universitas Katolik Widya Mandira \\ Email: sintusrunesi@gmail.com
}

\begin{abstract}
In his path of thinking, particularly from the 1930s onwards, Martin Heidegger firmly believed that Sein reveals itself, when human being, whom he termed as Dasein, awakened from his blindness of common sense and struggle for grasps his own authenticity. In this paper I examine Heidegger's destruction of the work of art as a site of strife between art and politics in his text, Der Ursprung des Kunstwerkes. Heidegger's position is complex: on the one hand, he acknowledges that Sein is a phenomenon beyond our horizon of understanding, Sein is all about not something particular; on the other hand, he insists that Sein's presence through art inscribed in a certain particular identity, especially German volks. In response, I argue that the identification of Sein with a particular identity such as German volks, offers the truth that the politics itself is forged and instituted in and as work of art. Some conclusions will be drawn concerning the importance of the small dimension of Heidegger's thought on art in contemporary politics.
\end{abstract}

Keywords: Heidegger, art, Sein, Dasein, politics, identity

\section{Pendahuluan}

Seni, pada masa lalu tak dapat dilepaskan dari ritual-ritual keagamaan. Karya seni menjadi medium manusia semasa itu, mengungkapkan sentimen religius mereka. Sebagai medium, sebuah karya seni merepresentasikan yangtransenden atau yang-kudus. Tarian misalnya, bukan hanya sebuah gerak tubuh. Ia adalah doa dan ritus, yang menghubungkan sang penari dengan yang-transenden. Maka, karya seni yang mencakup di dalamnya puisi, pertunjukkan drama, tarian bahkan lukisan memiliki kekuatan untuk menghantar dan memampukan seseorang mendengar sabda melalui matanya. Karya seni mampu mengubah persepsi dan pengertian para penganut agama, dengan cara yang mungkin bergerak di luar tata tertib logika, tetapi kebenaran dan keyakinan, yang sering memanifestasi melalui disposisi subjektif seseorang yang mengalaminya di 
hadapan kenyataan, sukar untuk subjek dari dalam diri. Dalam disangkal.

pemahaman seperti itu, Hegel

Namun, pada masa sekarang, menyatakan bahwa seni telah berakhir.

hubungan seperti itu hampir-hampir tak Artikel berikut adalah upaya lagi menjadi perhatian. Seni dalam satu mendalami filsafat seni Heidegger dan lain cara, dilepaskan dari referensi sebagaimana tertuang dalam teksnya Der semacam itu. Seni bukan lagi medium Ursprung des Kunstwerkes. ${ }^{2}$ Di sini, saya representasi, melainkan dalam nuansa akan memulai dengan (1) mengelaborasi Nietzschean, medium pelepasan problem interpretasi atas karya tersebut. rangsangan estetis subjek. Seni Dalam bagian ini, saya akan dikembalikan kepada subjektivitas menunjukkan bahwa kalau Hegel individual. Seni tidak lain tentang proses kreatif yang terjadi dalam diri subjek seniman maupun subjek penikmat. Bila kita memandang seni melalui lensa Nietzschean misalnya, seni tidak lain instrumen perwujudan kehendak untuk berkuasa, yang termanifestasi secara biologis melalui darah, detak jantung dan reaksi-reaksi lainnya. ${ }^{1}$ Seni dilepaskan dari referensinya dengan manusia sebagai homo religiosus. Membincang seni berarti membincang aesthesis, membincang pengalaman mengenai proses kreatif yang lahir karena rangsangan estetis yang dirasakan oleh

1 Cf. Martin Heidegger, "Five Statements of Art," (Frankfurt am Main: Vittorio Klostermann, 2003 [1977]) 73. Dalam penulisan ini saya akan menggunakan edisi Inggrisnya, yakni Martin Heidegger, "The Origin of the Work of Art," Off the Beaten Track, trans. Julian Young and Kenneth Haynes (Cambridge: Cambridge University Press, 2002). 
ditunjukkan bahwa teks tersebut tidak lain sebuah manifesto identitas, sebuah tempat pertarungan antara seni dan politik. Dalam bagian selanjutnya (4) pemikiran Heidegger akan dibaca dalam hubungannya dengan politik semasa ini. Di sini, saya akan membacanya dalam dua langkah evaluatif, yakni dengan melihat hubungan Heidegger dengan politik dan problem identitas lewat karyanya tersebut dan dilanjutkan dengan membaca politik kontemporer dengan bercermin pada perspektif Heidegger dalam karya tersebut. Artikel ini akan ditutup dengan sebuah simpulan kecil.

\section{Posisi-posisi interpretasi}

Sebelum menunjukkan interpretasi saya atas teks tersebut, akan disajikan secara ringkas pandangan beberapa pemikir. Setidaknya terdapat dua posisi interpretatif atas karya Heidegger, Der

${ }^{3}$ Untuk nama-nama yang disebut di sini menyangkut posisi interpretatif, kecuali Christopher Long, saya mengikuti uraian Joseph J. Kockelmans. Long saya tempatkan dalam satu posisi bersama Otto Pöggeler berdasarkan pemahaman saya atas artikelnya, "Art's Fateful Hour: Benjamin, Heidegger, Art and Politics," New Source German Critique, No. 83, Special Issue on Walter Benjamin, (2001) 89-115. http://www.jstor.org/stable/827790 (acces 03.08.2015). Otto Pöggeler dan Christoper Long yang saya sebut sebagai posisi radikal memahami karya Heidegger tersebut dalam hubungannya dengan politik karena menarik garis hubung dengan keterlibatan politisnya, sedangkan von Herrmann, Walter Biemel dan Joseph J. Kockelmans di lain pihak sebagai posisi
Ursprung des Kunstwerkes. Otto Pöggeler dan Christoper P. Long, yang saya sebut sebagai posisi radikal di satu pihak, dan Friedrich-Wilhelm von Herrmann, Walter Biemel dan Joseph J. Kockelmans sebagai posisi konservatif di lain pihak. $^{3}$ Menurut Pöggeler, karya Heidegger tersebut pertama-tama tidak memiliki kaitan dengan filsafat seni tetapi dengan pertanyaan mengenai Sein, sebagaimana tulis Heidegger dalam Adendum: "keseluruhan esai ini secara sadar bergerak, walau implisit, melalui jalan pertanyaan tentang hakekat sangAda."4 Berdasarkan pernyataan ini, Pöggeler menegaskan bahwa determinasi sebuah karya seni hanya dapat dimengerti dari perspektif pertanyaan mengenai kebenaran Sein dan kebenaran tentang Sein. Ia menegaskan kembali apa yang telah dinyatakan oleh Heidegger bahwa

konservatif lebih membatasi interpretasi mereka atas karya tersebut dalam lingkup seni. Walau begitu, saya menemukan bahwa kedua posisi ini tetap melihat karya ini dalam hubungannya dengan karya monumentalnya Being and Time. Untuk dua posisi ini, lihat Joseph J. Kockelmans, Heidegger on Art and Art Work, (Dordrecht: Martinus Nijhoff Publishers, 1986) 81.

${ }^{4}$ Heidegger, "The Origin of the Work of Art," 55; Cf. Otto Pöggeler, Martin Heidegger's Path of Thinking, trans. Daniel Magurshak and Sigmund Barber (New York: Humanities Press International Inc., 1987) 167; Lih. Kockelmans, Heidegger, 81. Cf. Martin Heidegger, "Letter on Humanism," Pathmark, trans. Frank A. Capuzzi (Cambridge: Cambridge University Press, 1998) 239. Penekanan oleh saya. 
seni berhubungan dengan peristiwa apropriasi, darinya makna tentang Sein dapat didefinisikan. Pöggeler lalu menyatakan bahwa karya tersebut adalah meditasi lanjut Heidegger atas Sein yang telah dimulai sejak karyanya Sein und Zeit.

Pöggeler selanjutnya mengungkapkan bahwa refleksi

Heidegger berangkat dari pengalaman keterlibatannya dalam politik pada periode yang mendahului kuliah tersebut. Salah satu petunjuk untuk interpretasi tersebut nampak dalam penggunaan istilah $\tau \varepsilon \dot{\chi} \chi v \eta($ technē) di awal teks, yang langsung mengingatkan kita pada isi pidato rektoratnya. Pöggeler menyatakan bahwa pada masa itu, Heidegger memang memfokuskan perhatiannya pada bahasa dan seni sebagai bagian dari upaya filosofisnya, setelah menarik diri dari keterlibatan politisnya, namun tetap memiliki keyakinan bahwa historisitas

5 Cf. Michael E. Zimmerman, Heidegger's Confrontation with Modernity: Technology, Politics and Art, (Bloomington: Indiana University Press, 1990) ch. 5; Cf. Martin Heidegger, "The Self-Assertion of the German University," The Heidegger Controversy: A Critical Reader, ed. Richard Wolin (Cambridge: MIT Press, 1998) 29-39.

6 Dalam catatan Christopher Long, hanya berbeda sebulan saja Benjamin dan Heidegger membincangkan seni. Benjamin pada tanggal 16 Oktober 1935 menulis sebuah surat kepada Horkheimer tentang upayanya melihat seni dalam hubungannya dengan politik. Dan dan takdir bangsanya ditentukan oleh spirit perjuangan bangsanya. ${ }^{5}$

Nada yang sama terdapat pada Christopher Long. Dengan membandingkan Heidegger dan Walter Benjamin, ${ }^{6}$ ia menyatakan bahwa esai Heidegger itu dapat dilihat sebagai sebuah respons terhadap kemungkinan politisasi seni, sekaligus sebuah upaya menghidupkan kembali aura seni ke dalam sebuah tatanan yang memungkinkan perlindungan terhadap relasi otentik antara asal-usul Geist dan kekuatan masyarakat Jerman yang mau ditegakkan lagi. Masih menurut Long, karya ini dapat dilihat sebagai respon terhadap ketakutan Benjamin yang melihat pudarnya aura seni karena pengaruh teknologi dan kemungkinan estetisasi politik lewat seni sebagai kekuatan baru fasisme.

Berbeda dengan Pöggeler dan Long, Friedrich-Wilhelm von Herrmann

pada 13 November 1935, Heidegger memulai kuliahnya tentang The Origin of the Work of Art di Freiburg. Christopher P. Long, "Art's Fateful Hour," 89-90. Di tempat lain, David Ferris menunjukkan bahwa kedekatan waktu tersebut, mengindikasikan kalau Benjamin mengetahui kuliah Heidegger mengenai karya seni di Freiburg (November 1935) dan di Zurich (Januari 1936). Lihat David Ferris, "Politics of the Useless: The Work of Art in Benjamin and Heidegger," Sparks Will Fly: Benjamin and Heidegger, eds. Andrew Benjamin and Dimitris Vardoulakis, (Albany, NY: SUNY Press, 2015) 277n. 
menyatakan bahwa teks-teks dalam Holzwege (Off the Beaten Track) mengandung garis besar pemikiran Heidegger tentang seni. Menurutnya, pernyataan Heidegger dalam Adendum di satu sisi, memerlihatkan usahanya merefleksikan seni dengan cara yang berbeda dari apa yang lazim dalam historiografi seni, yang bisa kita temukan pada para rasionalist, empirisist, Kant dan juga Hegel. Pada sisi lain, bila pertanyaan menyangkut kebenaran Sein sebagai pertanyaan sentral bagi filsafat, maka pertanyaan menyangkut makna seni dapat diungkapkan dari perspektif yang lebih menyeluruh. Kockelmans dan Biemel pun sejalan dengan von Herrmann yang yakin bahwa esai tersebut menjadi salah satu esai penting dalam keseluruhan pemikiran filsafat seni Heidegger, dan penting dicatat bahwa ia sendiri tidak pernah mencabut dirinya dari tesis dasar yang dikembangkannya: upaya yang berkanjang untuk menyelam ke dalam misteri Sein. ${ }^{7}$ Singkatnya, seni bagi Heidegger adalah salah satu jalan untuk mengalami Sang-tersembunyi.
Dalam bagian yang ditambahkan kemudian, ia bertanya apakah seni masih merupakan hal yang esensial dan seharusnya, melaluinya kebenaran yang terjadi menentukan eksistensi historis kita; atau memang peran itu telah berakhir, sebagaimana dinyatakan oleh Hegel. Jika seni tidak lagi memiliki peran semacam itu, maka pertanyaannya adalah mengapa demikian? Heidegger menyatakan bahwa penyelidikannya tentang seni yang dimulai dengan telisik tentang konsep "asal-usul” (Ur-sprung, arche) dimaksudkan untuk menampakkan hakekat kebenaran. Asalusul (Ur-sprung, arche) bagi Heidegger tidak pernah merupakan masa lalu, sebaliknya selalu tentang "tiba-padasaat-ini," atau "hari ini" karena ia menguasai dan mengarahkan seluruh sejarah ada. Asal-usul adalah tentang lompatan dari masa depan ke dalam saat ini. Oleh karena itu, bila Heidegger memahami karya seni sebagai kebenaran yang menubuh dalam sebuah karya, maka subjek di mana kebenaran itu menampakkan diri, bukan hanya tentang sebuah karya, tetapi tentang sebuah

\footnotetext{
${ }^{7}$ Kockelmans, Heidegger, 82.
} 
masyarakat, dan masyarakat yang muasal baru (Anfang) dalam sejarah dimaksud tidak lain bangsanya. ${ }^{8}$ Maka, pemikiran. Hal yang sama ia lakukan juga pembacaannya atas seni adalah momen dalam pemikirannya tentang filsafat seni. dalam perjuangan bangsanya untuk Menurutnya, filsafat seni tidak pernah menegaskan identitasnya. Jadi, dengan mencapai dirinya sendiri dan karena itu, melihatnya dalam konteks politik saat itu, ia ingin melakukannya, membawa seni Heidegger ingin menunjukkan bahwa pada kepenuhannya (Vollendung), pada penegasan identitas bangsanya tidak hanya diterima dengan berpaling pada warisan masa lalu melainkan harus pula menerima poesisnya dari masa depan. ${ }^{9}$

\section{Titik berangkat Heidegger}

Heidegger menarik garis batas antara dirinya dengan seluruh sejarah filsafat seni dalam tradisi Barat terutama dengan para pemikir klasik Jerman, yang dimulai sejak Baumgarten dan Kant. Ia memikirkan seluruh sejarah filsafat sejak pre-Sokratik sebagai sejarah penghilangan ada (Vergessenheit des Seins) dan menganggap dirinya adalah pemikir yang berhasil menemukan kembali ada itu. Seturut itu, ia menempatkan dirinya sebagai suatu titik

\footnotetext{
${ }^{8}$ Heidegger, "The Origin of the Work of Art," 21.

${ }^{9}$ Cf. ibid., 21.

${ }^{10}$ Bandingkan dengan pernyataannya dalam Being and Time: "Fulfilling (Vollendung) is a mode of 'finishedness' (Fertigkeit), and is founded upon it. Finishedness is itself possible only as a determinate form of something present-at-hand (Vorhandenen) or ready-to-hand (Zuhandenen)." Martin Heidegger,
} 
pembedaan 'sesuatu' dengan karya. Fase ketiga bermula pada era modern di mana selera atau citarasa didefenisikan sebagai relasi individualistik manusia dengan lingkungan sekitarnya, di mana manusia menjadi ukuran bagi eksis/beradanya sesuatu. Di sini, keindahan dilihat melulu dalam hubungannya dengan subjek, yakni persepsinya. Artinya, pada fase ketiga, kita mulai melihat sebuah pergeseran pemaknaan atas seni sebagai objek sensasi, aesthēsis.

Pada periode modern ini, seni yang berhubungan secara erat dengan 'yangabsolut' sebagaimana terjadi pada periode-periode antik, kehilangan fungsi representatifnya. Fase keempat ini ditandai oleh berakhirnya seni sebagaimana klaim Hegel. Di situ, seni hanyalah satu tahap yang mesti dilalui oleh Roh Absolut untuk sampai pada kesadaran akan dirinya sendiri. Fase kelima berawal pada abad ke-19 ketika Richard Wagner mencoba mengupayakan suatu hubungan baru antara seni dengan 'yang-absolut', tetapi hasilnya justru jatuh kepada hal-hal emosional dan akhirnya memuncak dalam ketiadaan atau nihilisme. Menurut Heidegger, meskipun kemabukan emosional dimaksudkan sebagai kompensasi bagi eksistensi manusia teknis, Wagner gagal menyediakan orientasi kepada puisi dan pemikiran. Dengan demikian, pada Nietzsche sebagai fase terakhir terjadi transformasi estetika ke dalam fisiologi melalui konsepsinya mengenai kemabukan emosional, yang diartikan sebagai fenomena syaraf dan tanggapan fisikoelektrik dari tubuh.

Dalam epilog yang ditambahkan kemudian, Heidegger menulis bahwa teks Der Ursprung des Kunstwerkes menjadi jalan keterlibatannya dalam teka-teki besar tentang seni. Teka-teki tersebut adalah seni itu sendiri, dan upaya tersebut tidak dimaksudkan untuk menjawab secara tuntas teka-teki tersebut: membawa seni kembali kepada dirinya sendiri. Di sini, sebenarnya Heidegger mengundang kita untuk membaca teks tersebut sambil menjaga tegangan tetap yang terdapat dalam klaimnya tentang, di satu sisi, percobaannya untuk menyelidiki teka-teki tersebut tanpa memberi jawaban, dan di sisi lain, upayanya memberikan kontribusi pada pengertian kita tentang esensi seni dalam kaitannya dengan nasib bangsanya. 
Untuk mewujudkan keduanya, Heidegger memberi kita dua petunjuk penting. Yang pertama terkait dengan asal mula estetika modern dan yang lainnya menyangkut nasib seni modern. ${ }^{12}$

Heidegger mengingatkan kita bahwa estetika merupakan cabang filsafat yang hadir kemudian dengan karya-karya seni sebagai objeknya, objek aisthēsis, tangkapan sensasi dalam artinya yang luas. Dalam hal ini, pengalaman subjektif manusia sangat menentukan, sebab darinya, kita memeroleh informasi mengenai esensi seni. Pengalaman menjadi sumber dan ukuran menyangkut apresiasi kita terhadap seni dan gayagaya dari produk artistiknya. Artinya, estetika berbicara tentang pengalaman. Namun, pengalaman itu juga menurut Heidegger menjadi elemen penting melaluinya seni secara perlahan-lahan berakhir. Ini disebabkan oleh cara penerimaan yang membatasi seni hanya pada hal-hal yang tampak mata. Terjadi reduksifasi Sein sekadar tampakan estetis, tergantung reaksi estetis subjek individual. ${ }^{13}$

12 Kockelmans, Heidegger, 83.
Tentang klaimnya itu, Heidegger mengutip beberapa pernyataan masyur dari Hegel sebagaimana terdapat dalam Lectures on Aesthetics:

"Sudah lama seni tidak lagi memberi harapan bagi kita sebagai cara tertinggi melaluinya kebenaran melindungi eksistensi dirinya sendiri."

"Seseorang barangkali berharap bahwa seni akan terus meningkatkan dan menyempurnakan dirinya, namun formanya berhenti menjadi kebutuhan tertinggi dari roh."

"Dalam keseluruhan relasi ini, seni sebagai dan juga yang tertinggal bagi kita, pada titik tertinggi dari panggilannya, telah menjadi masa lalu."14

Menurut Heidegger, pernyataan yang dilontarkan oleh Hegel tersebut, bukanlah sebuah ledakan besar yang mengakhiri seni, melainkan suatu resultante dari bertemunya beberapa faktor sosial yang dapat diidentifikasi, seperti perkembangan subjektivitas modern yang mencapai puncaknya pada masa romantik serta perkembangan teknologi. Dalam konteks modernitas, seni sebagai sebuah karya tidak lagi bertujuan untuk mencapai suatu totalitas pengertian tentang dan lewatnya historisitas Sein secara menentukan

\footnotetext{
${ }^{13}$ Heidegger, "The Origin of the Work of Art," 50.
}

${ }^{14}$ Ibid., 51. 
dijangkau, ${ }^{15}$ tetapi lebih diarahkan sebagai suatu ekspresi diri manusia dengan tujuan ekonomis. Pernyataan Schlegel mungkin bisa menggambarkan situasi ini: "dalam apa yang dinamakan filsafat kesenian, biasanya salah satu dari keduanya menjadi korban: filsafat atau kesenian". 16

Sedikit kembali pada Hegel. Bahwa karena asumsi dasarnya yang memandang sensibilitas itu lebih rendah dari yang intelektual, maka ia menempatkan seni hanya sebagai salah satu tahap melaluinya Budi Absolut berproses menuju puncak kesadarannya. Oleh karena itu, pandangan Hegel dianggap membuka arah baru pandangan manusia mengenai seni. Seni tidak lagi memiliki tujuan objektif, sebaliknya ditundukkan sepenuhnya pada subjektivitas setiap orang. Di situ, seni sebagai bentuk representasi dan mimetik diciutkan menjadi objek kesenangan subjektif, aesthesis. Perubahan ini berarti pula berubahnya pemahaman mengenai esensi kebenaran, terutama kebenaran mengenai manusia sebagai Dasein.

${ }^{15}$ Kockelmans, Heidegger, 80.

${ }^{16}$ Friedrich Schlegel seperti dikutip oleh Ignas Kleden, Sikap Ilmiah dan Kritik Kebudayaan, (Jakarta: LP3ES, 1987) 178.
Menurut Jacques Taminiaux, ambiguitas yang ada pada Heidegger dapat diartikulasi sebagai berikut: di satu pihak, Heidegger menyatakan bahwa teka-teki tersebut menyangkut seni itu sendiri, dan dengan cara yang sama mencoba mengatasi estetika sebagai salah satu bentuk metafisika modern. Artinya, Heidegger memang tidak mencoba mencari jawaban yang tuntas atas teka-teki tersebut. Tetapi di lain pihak, jelas bahwa Heidegger mempunyai pandangan yang positif mengenai pernyataan Hegel tersebut. Dan ia menyebut itu sebagai refleksi yang cukup menyeluruh mengenai esensi (Wesen) seni, lewatnya Sein dalam kecerlangannya mewahyukan diri. ${ }^{17}$

Dengan demikian menjadi jelas bahwa Heidegger dalam Der Ursprung, mencoba menelusuri ketersembunyian Sein tidak dengan menempatkan manusia sebagai pusat penyelidikannya seperti dilakukan oleh Hegel, tetapi dengan menyelidiki apa yang dihasilkan manusia di dalam dunianya. Heidegger ingin menyelidiki, pada titik mana, Sein itu

\footnotetext{
17 Jacques Taminiaux dalam Kockelmans, Heidegger, 84.
} 
dapat dikenal karena menghadirkan dirinya, di mana kehadiran itu menjadi sebuah penampakkan kebenaran (aletheia). Di situ ia melihat seni mengikuti Schelling _ $\quad$ sebagai Wahrheitsgeschehen, peristiwa

kebenaran, moment di mana kebenaran sebagai fajar keterbukaan (aletheia) merekah dengan seluruh kecerlangan dirinya. ${ }^{18} \quad$ Upayanya adalah menempatkan kembali seni sebagai bentuk representasi historisitas manusia, terutama bangsanya setelah periode keterpurukan akibat perang sebelumnya. Seni menjadi wajah tampak dari Sein yang tak tampak wajah, seni adalah pendaran kecerlangan Sein yang tak tampak mata pada identitas partikular tertentu, terutama pada diri bangsa Jerman.

Heidegger yakin bahwa suatu karya yang sejati, terutama karya seni secara ontologis memiliki fungsi penyingkapan (disclosive). Karya seni "membiarkan

18 Cf. Hammermeister, The German Aesthetic Tradition, 173.

${ }^{19}$ Martin Heidegger, "The Thinker as Poet," Poetry, Language, Thought, trans. Albert Hofstadter (New York: Harper \& Row, 2001) 9. Dalam pembacaan saya, meski tidak pernah menyebut nama Marx dalam karyanya ini, saya melihat Heidegger terpengaruh oleh pernyataan Marx melalui pembacaannya atas karya Ernst Jünger, The Workers. Pernyataan Marx yang saya maksud telah memengaruhi Heidegger adalah "The entitas menjadi". Oleh karena itu, ia percaya bahwa revolusi Jerman hanya bisa sukses kalau dipandu dan dibangun di atas karya para raja seniman seperti puisi-puisi Hölderlin. Bagi Heidegger, hanya dengan merangkum dan menutup metafisika, dalam istilahnya, mendestruksi metafisika, maka sebuah awal baru yang lebih baik bisa dimulai. Dalam hal ini, ia menempatkan dirinya satu langkah di depan Hegel dan Nietzsche: membangun puisi revolusinya sebagai manifestasi dari angin pemikirannya, terutama dalam analisanya atas karya seni sebagai suatu manifesto identitas: seumpama kupu-kupu yang bertengger di atas bunga, lalu menari bersama angin yang berlalu melalui padang. ${ }^{19}$

\section{Der ursprung des kunstwerkes: manifesto identitas}

Dengan menempatkan Dasein sebagai titik berangkat ontologinya,

social revolution of the nineteenth century cannot draw its poetry from the past, but only from the future. It cannot begin with itself before it has stripped off all superstition in regard to the past. ... In order to arrive at its own content, the revolution of the nineteenth century must led the dead bury their dead." Karl Marx, "The Eighteenth Brumaire of Louis Bonaparte," Karl Marx - Selected Writings, ed. David McLellan (Oxford: Oxford University Press, 2000) 331. 
Heidegger dalam proyek filosifisnya mencoba menjauh dari sudut pandang antroposentrik-filosofis tradisional.

Pertanyaan-pertanyaannya tidak dipusatkan pada cogito Cartesian tetapi pada perilaku dasar Dasein. Walau demikian, Heidegger tak mampu menjauh secara total dari antroposentrisme, melaluinya eksistensi manusia secara general dan eksistensi otentik secara partikular diwahyukan. Untuk itu ia memulai teksnya dengan memaklumatkan konsep tentang asalusul (arche). Bagi Heidegger, asal-usul (arche) adalah sesuatu dari dan melaluinya sesuatu itu hadir seperti apa adanya, dan sebagai apa adanya. Ini berarti kita berpikir mengenai kodrat, hakekat atau esensi sesuatu. Asal-usul juga adalah sesuatu yang memerintah dan mengatur seluruh sejarah Sein, karena itu, asal-usul tidak pernah menjadi masa lalu. Dari situ, kita bisa melihat bahwa eskatologi setiap karya seni, terutama puisi adalah membiarkan kebenaran menyingkapkan dirinya.

Oleh karena itu, lebih dalam lagi, kita akan menemukan bahwa pada Heidegger, hakekat atau esensi itu tidak memiliki hubungannya dengan eksistensi, atau aktus keberadaan suatu barang tertentu. Ia melihatnya dalam hubungan dengan sesuatu yang tetap terjaga dalam ketersembunyiannya. Bukan tentang kesatuan antara eksistensi dan esensi seperti dikenal dalam arus pemikiran Aristotelo-Thomistik, tetapi antara esensi dan ketersembunyian (lethe). Heidegger tidak menyibukkan dirinya dengan 'buah mangga' dan kemangga-annya, tetapi antara ke-manggaan (esensi) dan suatu ketersembunyian dibalik esensi tersebut. Dalam konteks ini, berarti, ketika ia berbicara mengenai karya seni, pertama-tama tidak tentang karya seni sebagai sesuatu (quid) yang terkomposisi oleh materi-forma, tetapi sebagai dialektika antara kodrat sebuah karya dengan sesuatu yang tersembunyi sekaligus membuka diri melalui kodrat karya seni tersebut.

Dalam teks Der Ursprung des Kunstwerkes ini, kita akan melihat sebuah gerak penalaran yang secara gradual-dialektis bergerak dari (a) karya seni sebagai sesuatu (quid) yang terkomposisi oleh materia dan forma; lalu (b) bergerak melalui karya seni sebagai arena tegangan antara yang tampak dengan sesuatu yang menampakkan 
dirinya melalui karya seni, antara alam pra-maknawi (bumi) dengan alam maknawi (dunia). Karya seni sebagai shekinah (untuk menyebutnya dalam kosakata biblis), suatu takhta tempat bersemayam kebenaran dalam ketersembunyiannya. Gagasan itu membawa pada (c) kontemplasinya mengenai hubungan antara ada dan pikiran, yang mana dalam ketersembunyian bahasa proyektif dari puisi, ada dan pikiran hadir bersama dan memanifestasikan identitas sebuah bangsa. ${ }^{20}$

Sehubung dengan hal tersebut, dalam membicarakan puisi, ia sampai pada keyakinan bahwa mereka yang mampu memuisikan ada adalah penjaga dan pemelihara keberlangsungan suatu bangsa. Lebih jauh karena dorongan untuk meletakkan ada secara historis, telah mendorongnya untuk menyamakan antara kebenaran seni dengan kebenaran identitas politis, terutama identitasnya sebagai orang Jerman. Bahkan dalam

\footnotetext{
${ }^{20}$ Martin Heidegger, "The End of Philosophy and the Task of Thinking," Basic Writings: From Being and Time (1927) to the Task of Thinking (1964), ed. David Farrell Krell (New York: Harper Collins Publishers, 1993) 445-446. Dalam bukunya yang lain ia menyebut masalah ini sebagai hubungan antara bahasa (Sprache) dan ada (Sein). Lih. Martin Heidegger, On the Way to
}

catatan hariannya ia menegaskan bahwa hanya orang Jerman saja yang mampu memuisikan $a d a .^{21}$

\section{Kerja: peralatan vs karya seni}

Heidegger memulai esainya dengan membuat tiga pembedaan penting: keberadaan barang-barang, peralatan (piranti/tools) dan karya-karya seni. Untuk memahami ini, Heidegger mengupayakan aplikasi baru terhadap pembedaan antara materia-forma warisan Aristoteles. Pada Aristoteles, materi-forma adalah unsur konstitutif suatu substansi yang menentukan substansi itu hadir sebagai 'apa' dengan 'keapaannya' yang khas. Konsep itu dimengerti dalam arti analog sehingga dapat diterapkan pada semua kenyataan yang ada. Heidegger mereformulasi ulang dengan menyatakan bahwa materi dan forma merupakan unsur-unsur pembatas bagi sesuatu yang dihubungkan dengan peralatan yang dipakai oleh manusia. Dengan membatasi pemikiran

Language, trans. Peter D. Hertz (New York: HarperOne, 1982) 9-10.

${ }^{21}$ Martin Heidegger, "Pondering II," Ponderings II-VI: Black Notebooks 1931-1938, trans. Richard Rojcewicz, (Bloomington: Indiana University Press, 2016) 21. Edisi Jerman, Martin Heidegger, Überlegungen II-VI, hrsg. Peter Trawny (Frankfurt a.M: Vittorio Klostermann, 2014) 27. 
mengenai materi dan forma hanya pada barang-barang yang dihasilkan melalui sentuhan tangan manusia, Heidegger mencoba membedakan antara sesuatu yang secara alamiah hadir dan peralatan di satu pihak dan karya-karya seni di pihak lain.

Menurut Heidegger, peralatan sebagai instrument yang menghubungkan kita dengan dunia, ditentukan oleh penggunaannya di antara barang apa saja dan pekerjaan kita. Peralatan dilihat dari fungsinya. Seperti barang-barang lain, peralatan penuh dalam dirinya ketika selesai digunakan dan bisa dipikirkan terlepas dari fungsinya dalam kerja. Tetapi berbeda dengan objek alamiah, peralatan hanya berarti ketika ia digunakan oleh manusia. Eksistensi peralatan hadir ketika ia digunakan. Peralatan berbeda dengan karya seseorang, dan karya itu sendiri mengatasi barang apa saja sejauh karya itu self-sufficient. Jadi peralatan menjadi sekadar barang bila ia tidak lagi digunakan, tetapi ia berbeda dari sekadar barang alamiah yang berada begitu saja karena telah ditentukan penggunaanya.

\footnotetext{
${ }^{22}$ Heidegger, "The Origin of the Work of Art," 13.
}

${ }^{23}$ Heidegger, Being and Time, $\S 15$.
Dengan mengambil contoh dari lukisan Van Gogh mengenai sepasang sepatu petani, ${ }^{22}$ pembedaan tersebut mengingatkan kita pada perbedaan yang dibuat oleh Heidegger mengenai sesuatu yang siap untuk di-tangan- $i$ (Zuhandenheit) dan sesuatu yang tersedia atau hadir di hadapan kita (Vorhandenheit) dalam Being and Time. $^{23}$ Peralatan termasuk pada kelompok barang-barang yang siap kita pergunakan yang mendukung keberadaan eksistensi kita dalam dunia, sedangkan barang-barang alamiah adalah bendabenda yang ada, yang teronggok begitu saja di hadapan kita.

Tentang "ke-apa-an" setiap barang, Heidegger membuat tiga pembedaan penting. Pertama, sebagai substansi lewatnya sifat-sifat bawaan atau aksiden 'sesuatu' (quid) menjadi nampak. Ini mengingatkan pada perbedaan antara substansi dan aksidens Aristotelian. Kedua, sebagai kesatuan dari beragam sensasi yang dapat ditangkap oleh indraindra kita. Dan yang terakhir sebagai fusi antara materi-forma. ${ }^{24}$ Yang pertama dapat dipakai pada semua yang ada

\footnotetext{
${ }^{24}$ Heidegger, "The Origin of the Work of Art," 11-12. Ketiga konsepsi ini berhubungan istilah-istilah dalam
} 
sejauh ada, walau pun tidak dapat menghadirkan "Sein" secara mutlak. Yang kedua, sering dimengerti dalam beberapa arti. Yang lain memahami kesatuan itu sebagai penjumlahan, yang lain memahaminya sebagai totalitas (Hegel), dan yang lainnya memahaminya sebagai forma (Aristoteles). Dan yang terakhir, sesuatu ada selalu berada dalam ketertentuannya atau keunikannya. ${ }^{25}$

Heidegger kemudian, dalam hubungannya dengan ketiga bentuk pembedaan di atas, menyatakan bahwa ketiganya menentukan cara kita memikirkan sesuatu menurut apa yang kita pikir. Ini tidak terbatas pada hal-hal partikular, melainkan secara universal mengenai semua yang ada. Cara tersebut adalah suatu modus melaluinya kita menghubungkan secara langsung pengalaman (Erfahren) kita dengan semua yang ada. ${ }^{26}$ Dalam hubungannya dengan karya (Werk), Heidegger menunjukkan pembedaan penting. Bahwa dengan bantuan peralatan sebagai instrument di tangan, kita dapat

bahasa Yunani: yang pertama, dihubungkan dengan term symbebekota, yang kedua dengan term aesthesis, dan yang ketiga dengan term morphe dan hyle.

${ }^{25}$ Kockelmans, Heidegger, 115-117.

${ }^{26}$ Heidegger, "The Origin of the Work of Art," 12. menghasilkan sebuah karya sekaligus memberi kita akses kepada dunia. ${ }^{27}$ Sebagai contoh adalah lukisan Van Gogh tentang sepasang sepatu petani. Di sini, sepatu yang ada dalam lukisan berbeda dengan sepatu sebagai barang yang objektif hadir di hadapan kita. Sekalipun demikian, sepasang sepatu yang terdapat dalam lukisan itu membantu kita untuk mengetahui apa kehidupan sang petani dengan segala kesukaran, kecemasan dan keterlibatannya. Jadi peralatan, selalu ditempatkan dalam hubungan dengan fungsinya untuk mengakses dunia.

Heidegger lalu melanjutkan bahwa lukisan Van Gogh mengungkapkan kepada kita apa itu peralatan seperti sepasang sepatu sebagai sesuatu yang benar. Melalui sebuah karya, esensi sebuah barang diketahui sebagai apa dan bagaimana penggunaannya. Itulah yang disebut sebagai kebenaran. Ia benar, karena mengungkapkan dirinya (aletheia) dalam hubungan dengan fungsinya. ${ }^{28}$ Maka dalam karya seni, kebenaran mengenai seiend (barang apa

27 Walter Biemel, Martin Heidegger: An Illustrated Study, trans. J. L. Mehta (New York: Harcourt Brace Jovanovich, 1976) 95-96.

${ }^{28}$ Heidegger, "The Origin of the Work of Art," 15. 
saja yang ada) menampakkan dirinya. Menampakkan (set) berarti "membawa pada posisinya" atau "hadir dalam keadaan" atau "menyembul keluar". Dalam sebuah karya seni, suatu ada apa saja (seined/ens) menampakkan dirinya ke dalam terang keberadaannya. Keberadaan suatu ada datang ke dalam keadaanya yang sejelasnya. Dan itulah kebenaran. Artinya, suatu karya seni menjadikan kebenaran masuk ke dalam peristiwa historis yang konkret. Inilah maksudnya ketika ia menulis bahwa karya seni mengungkapkan kebenaran.

Di sini, menjadi jelas bahwa ada perbedaan posisi antara Heidegger dengan Hegel terkait pemaknaan atas kebenaran dalam kaitannya dengan seni. Hegel melihat kebenaran mengenai seni telah berakhir ketika subjek sampai pada kepastian absolut mengenai diri (Self). Heidegger sebaliknya, membedakan antara kebenaran sebagai yang tak tertutup atau yang mengungkapkan dirinya (aletheia), sebagai ketersingkapan dengan kebenaran sebagai kepastian absolut mengenai diri, antara sejarah sebagai kedatangan kesadaran Absolut dan sejarah Sein. ${ }^{29}$ Yang menjadi masalah adalah bahwa pada umumnya sebuah karya seni tidak dihubungkan dengan kebenaran tetapi dengan keindahan. Lukisan misalnya, disebut sebagai sesuatu yang menghadirkan keindahan dan bukan kebenaran.

Untuk mengatasi ini, bersama Heidegger kita harus berpaling pada permulaan sejarah Barat yang dimulai di dunia Yunani. Di sana, Sein (Esse) dimengerti sebagai benar dalam arti sesuatu yang secara aktual/konkret ada dan dapat diindrai seperti sebuah lukisan, sebuah baju, sepotong kain. Aktualitas (Wirklicheit) adalah kata yang dipakai untuk menyebut tentang yang benar. Selain itu, menurut Hegel pada masyarakat Yunani, seindes (ens) merupakan hasil karya "Roh". Maka bagi Hegel, masyarakat Yunani hidup dalam suatu dunia artistik, sehingga mereka memahami barang-barang yang berada (ens in actu) dalam term karya seni. Begitu pula aktualitas itu dimengerti dalam term-term seperti phusis, kodrat, kelangsungan, sensasi (gambaran yang

${ }^{29}$ Kockelmans, Heidegger, 85. 
dapat ditangkap oleh indra-indra kita). Dengan begini, bagi Hegel, dunia Yunani adalah dunia yang dilimpahi dengan keindahan tetapi kurang memberi perhatian pada kebenaran. Dalam dunia Yunani, keindahan menjadi tudung/penutup yang menyembunyikan kebenaran. ${ }^{30}$

Dari penelusuran ini, Heidegger lalu menyatakan bahwa di Barat, historisitas seni berkorespondensi dengan historisitas kebenaran. Heidegger menulis, "the beautiful belongs to the advent of truth", keindahan selalu merengkuh kedatangan kebenaran (Ereignis). ${ }^{31}$ Itulah sebabnya ia menyatakan bahwa bila ada peralihan pemahaman mengenai esensi seni, dengan sendirinya pemahaman mengenai esensi kebenaran pasti berubah. Lewat adanya (seined), karya seni selalu menampakkan aktus beradanya (Sein) barang-barang (das Sein des seiendes). Penampakan sebagai ketaktersembunyian merujuk pada kebenaran setiap ada (ens) yang hadir lewat setiap karya. Melalui karya seni, ada itu sendiri (Being itself) menempatkan dirinya dalam karya. Seni

\footnotetext{
${ }^{30}$ Ibid.

${ }^{31}$ Heidegger, "The Origin of the Work of Art," 52.
}

adalah sesuatu yang menyediakan dirinya bagi aktus beradanya kebenaran. ${ }^{32}$

\section{Karya seni: topos kebenaran}

Dalam bagian ini, untuk menjelaskan hubungan antara karya seni dan kebenaran, Heidegger berpaling ke dunia antik Yunani. Dengan mengambil contoh dari reruntuhan kuil-kuil Yunani, dramadrama Yunani dan pertandingan Olimpic, ia membentangkan cara melaluinya kebenaran sebagai aletheia menjadi nampak dalam karya seni. Kuil, drama dan pertandingan di Olimpic secara implisit menunjukkan apa yang coba diupayakannya: dimensi ritual dari karya seni, sisi historisitasnya dan otoritas seni. Karya seni tidak menyangkut ketrampilan tetapi menyangkut pengungkapannya. Oleh karena itu, deskripsi Heidegger mengenai kuil secara dramatis dihubungkan dengan kemunduran dunia modern dan pudarnya aura dunia. ${ }^{33}$ Dalam upayanya mengeksplisitasi ketersingkapan kebenaran dalam hubungannya kuil-kuil tersebut Heidegger membedakan antara

\footnotetext{
${ }^{32}$ Ibid., 19.
}

${ }^{33}$ Ibid., 20. 
"bumi" dan "dunia". Kuil adalah medan perseteruan, pertarungan bumi dan dunia.

Bagi Heidegger, dunia tidak sekadar tempat koleksi benda-benda yang ditempatkan di hadapan kita atau pun bingkai yang memberi kesatuan sebagai sebuah koleksi. Tetapi lebih dari itu, seni bersifat subjektif melaluinya kita sebagai subjek lahir dan mati, nasib dan takdir membawa kita ke dalam keberadaan (Sein): kita menjadi berada. Dunia, lebih dari hal-hal alamiah yang nampak dan dapat dipersepsi, ia merupakan situasi di mana kita merasa seperti berada di rumah sendiri. Heidegger menyebutnya dunia yang mendunia (Welt weltet). ${ }^{34}$ Dunia bersifat historis, dan memberi kemungkinan bagi seseorang mengambil keputusan berhadapan dengan beragam hal yang mungkin kita tolak atau yang belum kita ketahui. Singkatnya dunia adalah kenyataan yang terkait dengan pengalaman subjektif individu.

Meski demikian, dunia tidak seluruhnya merupakan sebuah keterbukaan. Ia memiliki dimensi yang tak dapat dicapai atau diakses secara

${ }^{34}$ Ibid., 23.

${ }^{35}$ Ibid., 23: [protective grace of gods is gifted or is refused]. Pernyataan Heidegger ini mengingatkan pada utuh. Heidegger menyebutnya sebagai ruang yang berada di luar kita, tempat rahmat perlindungan para allah diterima atau disangkal. ${ }^{35}$ Dimensi keterbukaan dan ketersembunyian ini menghantar kita langsung kepada term 'bumi.' Bumi yang dimaksud adalah sesuatu yang menampak, menyembul keluar dan perlindungan atau naungan. Bumi itu self-dependent, tak bertenaga tapi tak mengenal kelemahan. Ia ibarat penjaga. Pada dan di atas bumi ini, dasar historisitas dunia manusia dibangun. Misalnya, di atas bumi itu berdiri kuil sebagai sebuah karya manusia.

Ketika sebuah karya seni di tempatkan dalam konteks sebuah perayaan, kita menyebut tindakan itu sebagai "menempatkannya sesuai..." Tetapi penempatan ini berbeda dengan "menempatkan" sebuah kuil sesuai ketentuannya, yang mana di dalamnya ditempatkan berbagai atribut religius, dan menjadi tempat masyarakat merayakan satu festival kudus. Di sini, menempatkan tidak sekadar berkaitan dengan tempat, tetapi malah ditentukan oleh tujuan dan

konsepsi Plato mengenai $\chi \omega ́ \rho \alpha$ (chora). Chora adalah sebuah dunia yang tak dapat dijangkau baik secara konseptual maupun secara indrawi. 
kepada siapa penempatan itu dilakukan. Ini disebut sebagai dedikasi, dan dedikasi selalu berkaitan dengan tindakan mengkhususkan, dan mengkhususkan selalu berarti "mengkonsekrasikan". Artinya menguduskan bagi pihak lain yang lebih tinggi. Ini nanti kemudian dihubungkan dengan tindakan berdoa yang mengandung di dalamnya penghormatan kepada martabat dan kebenaran allah. ${ }^{36}$ Bumi tidak sekadar bumi saja tetapi menjadi bumi yang kudus, tempat sakral, tempat yang dikhususkan. Dengan tindakan mengkhususkan, alam pra-maknawi diangkat ke taraf maknawi.

Bagi Heidegger, sebuah karya yang ditempatkan memiliki maknanya juga sebagai "membangun sebuah dunia". Sebuah karya yang ditempatkan di bumi membuka sebuah dunia dan memertahankan keberadaannya. ${ }^{37}$ Maka dunia dan bumi harus dipikirkan secara bersamaan. Membangun sebuah dunia berarti memelihara bumi dan ini memerlihatkan dua ciri khas dari esensi sebuah karya. Dunia dibangun di atas

\footnotetext{
${ }^{36}$ Ibid., 22

${ }^{37}$ Ibid., 24.
}

bumi dan bumi menampakkan dirinya lewat dunia. Walau tak terpisahkan, hubungan antara keduannya tidak pernah merupakan hubungan yang kosong, melainkan diwarnai pertentangan, pertarungan, perjuangan. Pertentangan atau pertarungan ini tidak dimengerti sebagai sebentuk pembubaran semua kesatuan yang dapat dirangkum oleh Sein atau di dalam karya seni, tetapi dipahami sebagai paduan terdalam (inner cohesion) dari elemen-elemen yang saling bertegangan. Prinsip kohesif yang memadukan adalah logos. ${ }^{38}$

Heidegger memakai kata seperti fight, struggle, strife untuk menunjukkan dimensi pertentangan antara dunia dan bumi, suatu tegangan kreatif. ${ }^{39}$ Oposisi antara dunia dan bumi, pertama-tama merupakan oposisi antara keterbukaanitu-sendiri dengan sesuatu yang tersembunyi di dalam keterbukaan tersebut. Di sini, karya seni menjadi medan/arena pertarungan (ketegangan kreatif) itu, dan kuil menjadi contoh yang gamblang mengenai keterbukaan dan sesuatu yang tersembunyi di dalam

\footnotetext{
38 William J. Richardson, Heidegger: Through Phenomenology to Thought, $4^{\text {th }}$ edition, (New York: Fordham University Press, 2003) 412.

${ }^{39}$ Heidegger, "The Origin of the Work of Art," 26
} 
keterbukaan tersebut. Kuil itu berdiri di luar bumi yang merupakan pelindungnya, sekaligus membuka pengetahuan kita tentang sebuah dunia. Ia memerlihatkan bagi kita dunia Yunani, budaya mereka, dan siapa allah mereka. Jadi esensi sebuah karya terletak dalam ketegangan kreatif antara dunia dan bumi dan menjadi tanda bagi sebuah dunia yang tertentu. Esensi sebuah karya seni nampak dalam setiap pertarungan. Dalam pertarungan itulah kebenaran menampakkan dirinya. $^{40}$ Karya seni adalah topos dari kebenaran.

Bumi dikenal lewat dunia, dan dunia menempatkan dasarnya di atas bumi hanya sejauh kebenaran menyingkapkan diri lewat pertarungan antara keterbukaan dan ketersembunyian. Artinya, lewat karya seni, bumi dibiarkan menjadi bumi lewat dunia yang terbangun di atas bumi. $^{41}$ Jalan, lewatnya kebenaran menampakkan diri adalah esensi sebuah karya manusia yang mengandung

40 Bandingkan dengan gagasannya mengenai kodrat

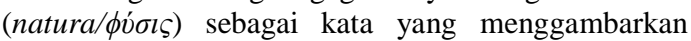
keterbukaan, seperti cahaya yang menyinari sesuatu sehingga sesuatu itu dapat masuk kedalam kehadiran, menunjukkan dirinya dalam kehadirannya. Cf. Martin Heidegger, The Elucidations of Hölderlin's Poetry, trans. Keith Hoeller (New York: Humanity Books, 2000) 78-79. keterbukaan sekaligus ketersembunyian.

Membangun sebuah dunia dan memelihara bumi, yakni lewat karya sebagai pusat pertarungan, melaluinya $a d a$ yang menampakkan dirinya sebagai sebuah keseluruhan atau kebenaran menjadi hadir secara utuh. Kebenaran menampakkan diri lewat sebuah kuil yang berdiri di sana yang membuat bumi menjadi 'sakral', tempat yang kudus (Bezirk). ${ }^{42}$ Ini tidak berarti sesuatu secara benar digambarkan atau dibangun pada suatu tempat, tetapi bahwa sesuatu sebagai sebuah keseluruhan dibawa masuk ke dalam sebuah keterbukaan/ketersingkapan dan berada di sana. Ia menampakkan yang tak terlihat namun memberi nuansa kesatuan ekstasis. ${ }^{43}$

Lewat sebuah karya seni, penampakan diri ada menjadi jelas atau terang di hadapan kita. Jenis cahaya ini menempatkan kecerlangannya dalam sebuah karya, sebuah kebenaran yang

\footnotetext{
${ }^{41}$ Otto Pöggeler menulis bahwa konsepnya mengenai earth merupakan tahap penting dan menentukan pemikiran Heidegger mengenai seni dalam periode sesudahnya. Lih. Pöggeler, Martin Heidegger's Path of Thinking, 167.

42 Cf. Karsten Harries, Art Matters. A Critical Commentary on Heidegger's "The Origin of the Work of Art," (New York: Springer, 2009) 43.

${ }^{43}$ Heidegger, "The Origin of the Work of Art," 32.
} 
bercitra/berpamor (veritatis splendor). terkandung apa yang kita sebut sebagai Terang yang ditempatkan ke dalam "posisi" atau "pendirian." Lebih jauh sebuah karya itu adalah keindahan. Maka lagi, esensi kebenaran menyata lewat keindahan menjadi jalan lewatnya tindakan politis yang bisa kita temukan kebenaran sebagai ketersingkapan dalam pendirian sebuah negara.

dibawa ke dalam kehadiran. ${ }^{44}$ Esensi Oleh karena itu, Heidegger sebuah kebenaran menjadi jelas, terbuka lewat karya seni sekaligus esensi tersebut mengandung kebenaran. Hal ini mengafirmasi gagasan awal yang mendefinisikan hakekat sebuah produk dalam relasinya dengan esensi kebenaran sebagai ketersingkapan ada.

\section{Revelasi sein melalui bahasa}

Seni adalah fundasi karya seni dan seniman. Fundasi itu sekaligus menjadi sumber atau asal (Ursprung als Anfang) bagi esensi lewatnya ada (Sein) yang mau dihadirkan menjadi ada (seiend) secara aktual. Aktualitas sebuah karya hadir lewat objek karya yang dihasilkan sebagai 'peristiwa kebenaran' (Wahrheitsgeschehen). Dan menyebut peristiwa berarti kita memikirkannya dalam hubungan pertentangan antara dunia dan bumi yang terjadi pada dan lewat karya seni. ${ }^{45}$ Dalam karya seni menghubungkan esensi kebenaran yang nampak dalam sebuah karya seni dengan pemeliharaan (die Bewahrung). Memelihara sebuah karya seni berarti 'masuk dalam' sebuah penyingkapan Sein lewat esensi karya seni. Yang dimaksud dengan "masuk dalam" merujuk pada sebentuk pengetahuan yang melibatkan diri dalam karya-karya tersebut. Bentuk pengetahuan ini menuntut juga kehendak dari subjek yang terlibat. $^{46}$ Pengetahuan mengandaikan kehendak, dan kehendak mengandaikan pengetahuan dari Dasein yang mengangkatnya dirinya ke dalam kesadaran akan Sein yang menyingkapkan adanya dalam pengalaman harian, yang sering tak disadari. Sikap ini hadir lewat keputusan yang ia sebut sebagai Entschlossenheit (ketekadan). Entschlossenheit tidak sebatas tindakan subjek melainkan 
keterbukaan Dasein yang keluar dari kungkungan inotentisitas adanya, dan membuka dirinya kepada Sein. ${ }^{47}$

Dalam hubungan dengan otentisitas Dasein dalam keterlemparannya sebagai sebuah upaya pemeliharaan diri, Heidegger lalu membaca karya seni dalam garis pemikiran tersebut. Pemeliharaan terhadap karya seni tidak berarti mereduksi seseorang hanya pada pengalaman privat mereka, tetapi membawa mereka ke dalam suatu hubungan mendalam dengan esensi kebenaran dalam karya-karya seni. Lewat tindak pemeliharaan terhadap warisan kultural misalnya, subjek menemukan dirinya dalam hubungan dengan orang lain (Mit-ein-ander-sein) yang menjadi dasar historis eksistensi manusia (Dasein), yang selalu mengalir keluar dari relasi dirinya dengan yang lain sebagai penyingkapan. ${ }^{48}$ Maka, dalam terang keberadaan suatu karya seni, sang pemelihara sekaligus menjadi pencipta, dan karena itu pula karya seni secara mutlak, dalam esensinya, membutuhkan pemelihara. $^{49}$
Dalam karya seni, esensi kebenaran nampak padanya, sekaligus menjadi cara berada dari karya seni. Jika kodrat esensial seni dalam perkembangannya secara spesifik hadir sebagai menempatkan-diri-dalam-kebenaran, maka menempatkan diri dalam karya berarti membawa adanya karya tersebut ke dalam tindakan dan peristiwa. Peristiwa itu tidak lain adalah pemeliharaan. Dengan demikian, seni adalah suatu proses ke arah menjadi dan peristiwa kebenaran. Penyingkapan terjadi dan kecerlangan dari setiap ada menyingkap, meskipun ketersingkapan yang datang itu lebih sebagai "proyeksi" ke masa depan dalam faktisitas "keterlemparan". 50

Kebenaran sebagai ketersingkapan sekaligus ketersembunyian, menyata melalui puitisasi ada. Seni dimaknai sebagai membiarkan tersingkapnya ketersembunyian itu sendiri melalui puisi. Puisi bagi Heidegger yang didasarkan pada bahasa, dalam dirinya harus dimengerti tidak sekadar sebuah tindakan komunikasi. Sebaliknya bahasa

\footnotetext{
47 Heidegger, Being and Time, §60: 295-301. $49 \quad$ Ibid., 44.

48 Heidegger, "The Origin of the Work of Art," $50 \quad$ Ibid., 44.
} 
dan puisi dikonstruksi oleh Heidegger sebagai dasar bagi seluruh karya seni seperti arsitektur, lukisan, kriya, dan musik, dan lain-lain. Semua karya seni harus menemukan kembali asalmuasalnya dalam puisi dan bahasa. ${ }^{51}$ Lewat bahasa, yakni penamaan, sesuatu yang ada menjadi jelas kehadirannya. Maka penamaan atau penyebutan merupakan penyingkapan diri agar menjadi jelas bagi pihak lain. Sesuatu yang dinyatakan melalui bahasa hadir ke dalam realitas sebagai sesuatu (“as"). Kita sampai kepada sesuatu itu sendiri yakni Sein yang menyatakan dirinya 'melalui' (medium quo) bahasa, dan bukan sampai kepada bahasa yang membahasakan sesuatu.

Mengenai penamaan tersebut, menarik kalau dibandingkan dengan pemikiran Walter Benjamin tentang bahasa. Menurutnya, bahasa sebenarnya bukan hak istimewa manusia, melainkan satu momen yang melekat pada segala sesuatu, sebagaimana ditunjukan dalam percakapan sehari-hari. Sehari-hari kita

${ }^{51}$ Long, “Art's Fateful Hour," 105.

52 Cf. Paul Budi Kleden, "Memasang Punggung ke Masa Depan - Menyisir Jejak Masa Lampau: Menyimak Filsafat Sejarah Walter Benjamin," Mengabdi Kebenaran, ed. Frans Ceunfin dan Felix Baghi (Maumere: Ledalero, 2005) 89-134. berbicara tentang bahasa musik, bahasa teknik, bahasa tubuh dan sebagainya. Dalam penggunaan seperti itu, bahasa adalah prinsip yang mengatur penyampaian makna-makna ideal dari sesuatu. Bahasa menyampaikan makna, namun bahasa bukanlah makna itu sendiri. Itu berarti, bahwa melalui bahasa sebagai pengungkapan kita tidak sampai ke sesuatu itu sendiri (realitas kelihatan), yang mengungkapkan dirinya melalui bahasa, melainkan kita sampai kepada sesuatu, yang mengungkapkan dirinya $d i$ dalam bahasa. ${ }^{52}$ Dalam ungkapan yang sama berarti, melalui karya seni sebagai ikon, kita tidak sampai ke sesuatu itu yakni karya seni tertentu yang hadir di hadapan kita, tetapi kita dihantar melampaui yang hadir untuk sampai kepada sesuatu yang mengungkapkan sebagian dirinya di dalam karya tersebut. ${ }^{53}$

Bahasa menunjukkan dimensi proyektif dari upaya menyingkapkan Sein. Rancang-bangun (Entwerfen) adalah modus operasional keterlemparan

${ }^{53}$ Lih. Martin Heidegger, Hoseki Shin'ichi Hisamatsu, et al., "Art and Thinking: Protocol of a Colloquium on May 18, 1958," trans. Carolyn Culbertson and Tobias Keiling, Philosophy Today, Vol. 61, Iss. 1 (Winter 2017): 47-51. [doi: 10.5840/philtoday2017317146]. 
ada (Wurf) sebagai penyingkapan yang membawa dirinya sendiri ke dalam adanya (ex-sistere), sesuatu yang telah tetapi belum vice versa. Maka "menyatakan" diri sekaligus berarti "membuang" hal-hal yang tidak perlu, yang membuat ada menjadi sesuatu yang tidak autentik. "Menyatakan" berarti sekaligus mengkonstitusi "membuang". Penyebutan atas sesuatu selalu meniadakan 'yang lain' yang tidak termasuk dalam penyebutan tersebut. Gagasan ini mengingatkan akan pandangan Hegel mengenai negativitas internal. ${ }^{54}$

Heidegger membangun pandangannya tentang seni dengan konsepsi tentang puisi sebagai "perkataan proyektif" (entwerfende Sagen). Puisi menjadi sarana yang paling memadai dalam membahasakan dunia maknawi dan alam pra-maknawi, membahasakan medan pertarungan dan

${ }^{54}$ Heidegger, "The Origin of the Work of Art," 46. Pernyataan ini bersifat sangat Hegelian. Ini mengingatkan tentang prinsip negativitas dalam Hegel. Apropriasi atas diri sekaligus mengandaikan penegasan atas bukan-diri. Misalnya, menyatakan bahwa "meja bukan laptop" berarti menyatakan bahwa "laptop" yang terletak di atas "meja" sebagai sesuatu yang negatif, yang dinegasi sekaligus disyaratkan oleh identitas "meja" sebagai "meja". Itulah yang disebut sebagai negasi internal. Penjelasan mengenai negativitas Hegelian ini dapat dibaca pada Martin Heidegger, tempat dari semua 'kedekatan' sekaligus 'keberjarakan' (Nähe und Ferne) dengan Sang Ada. Puisi adalah cara pembahasaan kita atas upaya untuk terusmenerus memberi akses lewatnya sang ada merevelasikan diri. Lewat puisi, sebuah dunia historis menghadirkan dirinya di hadapan masyarakat (einem Volk). Di sini, pemikir maupun penyair hanya memproyeksikan apa yang diproyeksikan kepada mereka. Proyeksi dalam dirinya mesti menjadi sesuatu yang diproyeksikan, yakni Ada (Seyn). Maka proyeksi tidak lain suatu peristiwa apropriasi (Ereignes). ${ }^{55}$ Kata-kata proyektif mengungkap sekaligus tidak mengungkap, menyingkap sekaligus menyembunyikan. Dalam bahasa-bahasa proyektif tersebut, konsep mengenai esensi dari historisitas masyarakat, termasuk juga sejarah dunia dibentangkan kepada setiap orang. ${ }^{56}$ Pada titik ini, kita melihat bahwa Heidegger

Hegel, trans. Joseph Arel and Niels Feuerhahn (Bloomington: Indiana University Press, 2015) 12 et seq.

55 Martin Heidegger, "Ponderings XIV," Ponderings XII-XV: Black Notebooks 1939-1941, trans. Richard Rojcewicz (Bloomington: Indiana University Press, 2017) 133. Edisi Jermannya, Überlegungen, XII-XV: Schwarze Hefte 1939-1941, hrsg. Peter Trawny (Frankfurt am Main: Vittorio Klostermann, 2014) 169. ${ }^{56}$ Heidegger, "The Origin of the Work of Art," 46. 
sudah bergerak dari subjek individual (Dasein) kepada subjek kolektif (das Volk/Volksein).

Dalam pengertian ini bahasa adalah puisi, sebab ada disingkapkan sebagai ada hanya melalui penciptaan (poesis=techne $=$ art $). \quad$ Puisi dalam bentuknya yang paling awal adalah penciptaan itu sendiri. Bahasa bukan puisi karena ia adalah ciptaan awal (urpoesy), sebab poesy hanya bisa ditangkap lewat bahasa, dan dalam bahasalah terungkap secara jelas asal-muasal puisi. Dan bila seni adalah penyingkapan Sein, lewat karya, berarti karya itu adalah puisi. Puisi sebagai seni, yang nampak sebagai sebuah karya seni menjadi medan penyingkapan Sein. ${ }^{57}$ Dalam karyanya yang lain, ia menulis bahwa bahasa adalah suatu wilayah yang sangat murni dari segala bentuk penguasaan, tetapi pada moment tertentu ketika ia dikuasai oleh seseorang, bahasa menjadi wilayah yang berbahaya dari segala bahaya. Bahasa menjadi sesuatu yang berbahaya

${ }^{57}$ Ibid.,46.

58 Terangkum dalam rumusan berikut: "Language is the danger of all danger because it first creates the possibility of a danger. Danger is the threat that beings pose to being itself. But it is only by virtue of language at all that man is exposed to something manifest: beings which press upon him and inflame him in his existence, karena ia menghadirkan Sein ke dalam keberadaannya. Ini berarti, dengan menguasai bahasa, seseorang menjadi author yang memiliki autoritas untuk menyatakan dan mengarahkan jalannya sejarah. $^{58}$

Seturut itu, Heidegger menyatakan bahwa esensi seni adalah bahasa, dan esensi puisi adalah keberadaan, penyingkapan Sein. Di sini, keberadaan mengandung tiga makna yang saling berelasi. Pertama, sebagai pemberian. Keterlemparan Dasein sebagai sebuah historisitas adalah sebuah pemberian. Kedua, sebagai dasar. Ini berkaitan dengan pengangkatan diri atau transendensi Dasein yang mengatasi waktu, seolah-olah berdiri di luar waktu. Dan yang terakhir, sebagai awal atau titik awal, pijakan awal bagi Dasein dalam memproyeksikan masa depannya, pijakan awal bagi pengejaran cita-cita Dasein. ${ }^{59}$ Keberadaan itu secara actual hadir dalam pemeliharaan, maka setiap bentuk keberadaan selalu

\footnotetext{
or nonbeings which deceive and disappoint him. Language first creates the manifest place of this threat to being, and the confusion and thus the possibility even of the loss of being, that is - danger." Heidegger, The Elucidations of Hölderlin's Poetry, 55.

${ }^{59}$ Heidegger, "The Origin of the Work of Art," 46-47. Cf. Long, "Art's Fateful Hour," 106-107.
} 
berkorespondensi dengan bentuk Proyeksi atas puitisasi kebenaran pemeliharaan tertentu atas manusia, yang melahirkan tataan-tataan politis tertentu.

Yang pertama, puisi dalam dirinya berarti menjadikan-hadir ada dan menetap sebagai sesuatu melaluinya kebenaran sebagai penyingkapan diinstitusikan ke dalam sebuah tatanan yang ada. Menempatkan-ke-dalam-karya selalu memberi dorongan untuk bergerak ke arah sesuatu yang berada di luar kebiasaan dan menghancurkan apa yang tertata. Di situ, kebenaran yang menyingkapkan dirinya dalam sebuah karya seni tidak dapat dibuktikan atau diambil dari sesuatu yang telah lewat. Sesuatu yang telah lewat disangkal melalui sebuah karya seni. Dengan demikian, sebuah keberadaan memiliki karakter sebagai sesuatu yang mengalir keluar, sebagai sebuah pemberian yang tidak kembali. ${ }^{60}$

Yang kedua, proyeksi puitis mengenai kebenaran ditempatkan dalam sebuah karya seni. Di sini, kebenaran diserahkan kepada si pemelihara, yakni dalam historisitas kemanusiaannya.

${ }^{60}$ Ibid., 47.

${ }^{61}$ Mengenai konsep keabadian lihat Martin Heidegger, Hölderlin's Hymns Germania and the Rhine, trans.

William McNeill and Julia Ireland, (Bloomington: Indiana University Press, (2014), 52ff.

${ }^{62}$ Heidegger, "The Origin of the Work of Art," 47. 
Yang ketiga, pemberian dan fundasi memiliki dalam diri mereka karakter 'kemendadakan' atau 'ketak-terdugaan' yang oleh Heidegger disebut sebagai awal atau permulaan. Permulaan/awal yang murni itu merupakan sebuah "Ursprung", sebuah lompatan asali. Lompatan itu sendiri bersifat primordial namun bukan primitif, karena secara fundamental diarahkan langsung ke masa depan. Namun apa yang diarahkan langsung ke masa depan tidak mengindikasikan bahwa terdapat masa lalu. Bagi Heidegger, permulaan ini tidak pernah menjadi masa lalu, ia selalu hadir sebagai "saat ini", "hari ini", karena ia menguasai dan mengarahkan seluruh sejarah ada. Asal-mula sebuah karya seni adalah permulaan bagi pencipta dan pemelihara. Maka seni bisa kita sebut sebagai penghadiran dimensi historis Dasein atau sebuah masyarakat. Historis tidak merujuk kepada pengertian tentang kesinambungan (duree), rangkaian waktu; tetapi tentang hubungan antara kesadaran dan $a d a$. Seni dalam esensinya adalah sebuah permulaan (Ursprung): sebuah jalan khusus lewatnya kebenaran hadir ke dalam kekonkretan secara spasio-temporal, dan karena itu ia menyejarah, menghubungkan antara kesadaran tentang identitas dan keberadaan dengan identitas tertentu. ${ }^{63}$

Seni adalah upaya menampakkan kebenaran. Sebagai sebuah upaya dari Dasein, ia memiliki historisitasnya. Seni adalah sejarah dalam artinya yang sangat mendasar, sebab ia menjadi basis, awal mula sejarah dan identitas Dasein. Dan menurutnya, hal tersebut nampak secara paling otentik dalam puisi. Lewat puisi, Sein menyingkapkan, merevelasikan dirinya. Hemat saya puisi sebagai karya seni dalam Heidegger adalah wajah tampak dari Sein yang tak tampak wajah. Heidegger dalam bukunya yang lain menegaskan bahwa kita mengalami revelasi Sein secara paling otentik tidak melalui ilmu pengetahuan yang membedah, memecah-mecah kenyataan tetapi "melalui filsafat primordial, sebagaimana melalui puisi-puisi agung dan proyeksi-proyeksi maknanya. Puisi

63 Ibid., 49. 
memungkinan keberadaan sesuatu menjadi lebih berarti. ",64

Pertanyaan yang mencuat adalah gejala apa yang menentukan dalam sebuah puisi sehingga oleh Heidegger dinyatakan bahwa puisi membuat ada menjadi sungguh ada dalam keotentikannya? Tak dapat disangkal bahwa gejala yang mencuat adalah pengolahan bahasa. Puisi adalah olahan bahasa, bahasa yang membahasakan dirinya, bahasa yang dialami sebagai bahasa. ${ }^{65}$ Bahasa sebagai suatu wilayah yang sangat murni dari segala bentuk penguasaan dan sebagai rumah manusia adalah sesuatu yang berbahaya. Ia berbahaya sebab dengan menguasai bahasa, seseorang dapat mengarahkan peristiwa kebenaran agar melayani kepentingannya. Bahasa mengarahkan proyeksi yang diartikulasi oleh Dasein sesuai impiannya. Dalam The Thinker as Poet, ia menulis bahwa: ${ }^{66}$

Saat kuncup awal cahaya pagi, dalam sunyi merayapi bubungan bebukit kegelapan dunia tak pernah meraih cahaya sang Ada (namun) kita terlalu larut bagi dewa-dewa, juga terlalu

${ }^{64}$ Martin Heidegger, The Essence of Truth: On Plato Parable of the Cave and the Theaetetus, trans. Ted Sadler (London: Continuum, 1994) 47.

${ }^{65}$ Cf. Martin Heidegger, "The Way to Language," Basic Writings: From Being and Time (1927) to the pagi untuk Ada. Ada sang puisi baru saja menyingkap, ialah manusia.

Bahasa berbahaya sebab ia bukan lagi tempat pemeliharaan tradisi sebagaimana ditegaskan kemudian oleh Gadamer, sebaliknya menjadi tempat pengerasan dan pembekuan ideologi penguasa sebagaimana dinyatakan oleh Foucault. Seni, dengan demikian menjadi pengindah penampilan yang menyembunyikan naluri penghancuran sekaligus menggelapkan (verdunkelt) kebenaran. Seni menjadi medium melaluinya setiap kekuasaan yang berjuang bagi dirinya mereproduksi kebohongan dan menghancurkan kebenaran.

\section{Reduksifasi seni: topeng dan propaganda politik}

Seni, seperti bahasa bagi Heidegger, bukanlah sebuah jalan yang bersifat provisional. Seni adalah jalan penegasan partikularitas identitas. Dalam karya seni, terutama melalui puisi, identitas itu dijaga dan dipelihara. Heidegger menulis dalam Being and Time bahwa "makna

Task of Thinking (1964), ed. David Farrell Krell (New York: Harper Collins Publishers, 1993) 406.

${ }^{66}$ Heidegger, "The Thinker as Poet," 4. 
ada dari Dasein bukanlah sesuatu yang lain, yang terlepas dari dan di luar dari Sein, melainkan adalah Dasein yang memahami diri sendiri." ${ }^{67}$ Ini berarti, Sein tersingkap tampil, memerlihatkan dirinya pada setiap momen keberwaktuan, kala manusia memahami dirinya dan memahami ke mana dirinya akan terarah. Dengan demikian penelaahan atas eksistensi-eksistensi melaluinya manusia sebagai Dasein keluar (ek-sistensi) adalah upaya menangkap kehadiran Sein secara penuh.

Heidegger dalam Der Ursprung des Kunstwerkes, berhasil membawa kita menelusuri, menyisir jejak-jejak kemungkinan Sein menampilkan diri dalam fenomen-fenomen karya seni, lewatnya manusia sebagai Dasein terlibat di dalamnya. Dalam karya seni, kebenaran sebagai penyingkapan menjadi nampak lewat tegangan kreatif antara dimensi keduniawian dan dimensi kealamiahan kenyataan. Di sini, dunia mewakili fenomena khas manusia dan bumi mewakili kenyataan alamiah. Dan

\footnotetext{
${ }^{67}$ Heidegger, Being and Time, §65, 325 .

68 Sebagaimana dikutip oleh Martinho G. da Silva Gusmão, Hans-Georg Gadamer: Penggagas Filsafat Hermeneutik Modern yang Mengagungkan Tradisi, (Yogyakarta: Kanisius, 2012) 131.
}

dari tegangan kreatif ini mengemuka sebuah tema penting lain yakni penegasan diri. Dalam ungkapan Gadamer berarti ada gerak antara "tinggal-di-dalam-diri-sendiri” (In-sichstehen) dan membuka-cakrawala-dunia. Dinamika ini bersifat kreatif sehingga terciptalah suatu "dunia baru" atau cakrawala baru dan bukan sebuah "bumi" yang tumbuh belaka. Seturut itu, dunia kehidupan tampak di situ, mengejawantahkan kehidupan justru karena ia tinggal-dalam-dirinya-sendiri di atas "hakekat bumi." 68

Lewat seni sebagai bentuk penegasan diri, kita dibimbing untuk menyelami diri dan mengenal diri, menyingkapkan diri dan mengarahkan diri agar menjadi otentik dan memuncak lewat puitisasi $a d a$. Bagi Heidegger, puisi tidak bertaut dengan investigasi literatur tetapi sebagai situs lewatnya historisitas dan takdir Dasein yang dikonfigurasi, dan kemudian menghadirkan dirinya sendiri. Lewat puisi, Dasein menjadi 'gembala' Ada. ${ }^{69}$ Situs (tempat) dalam

69 Lih. Otto Pöggeler, "Heidegger's Political SelfUnderstanding," The Heidegger Controversy: A Critical Reader, ed. Richard Wolin (Cambridge: MIT Press, 1998) 223. 
dirinya mewahyukan dimensi vertikal dan horizontal yakni dimensi metafisis sekaligus politis Dasein. ${ }^{70}$ Maka, subjek yang dibicarakan dalam elaborasi atas puisi-puisinya bukan hanya 'aku' individu, juga 'kita' yakni historisitas Dasein yang supraindividual, yang tidak lain adalah Jerman sebagai kesatuan dari keseluruhan yang ditegaskan. Sehubung dengan hal ini, dalam bukunya yang lain, ia malah menegaskan bahwa "hanya seorang Jermanlah yang mampu memuisikan Sein secara baru. "71

Puisi merupakan medium penyingkapan sekaligus penyembunyian ada (Sein), puisi merangkum keseluruhan kediaman manusia ke dalam kodratnya yang otentik, sebagai ada yang hadir. Penyingkapan dan penyembunyian itu memerlihatkan bahwa puisi sebagai karya seni bersifat historis. Historis sebab puisi terkait dengan pengalaman-

\footnotetext{
${ }^{70}$ Heidegger secara mendalam mengulas konsep situs (tempat) ini dalam sebuah suratnya kepada Ernst Jünger berjudul "Über »Die Linie«". Selengkapnya dapat dibaca dalam Martin Heidegger and Ernst Jünger, Correspondence, 1949-1975, trans. Timothy Quinn, (London: Rowman \& Littlefield Int'1, 2016), Martin Heidegger, The Question of Being, trans. with intro. by William Kluback and Jean T. Wilde (New York: Twayne Publishers Inc., 1958). Dalam surat tersebut, Heidegger mengkritik gagasan Jünger, yang melihat nihilisme sebagai suatu jalan yang harus dilalui, melainkan sebagai suatu tempat atau wilayah tempat kita mendiaminya.
}

pengalaman eksistensial yang tidak mudah diungkapkan dalam konsepkonsep yang jelas dan terpilah. Historisitas (Geschichtlichkeit) Dasein yang hadir, ada-di-dalam-dunia selalu merupakan ada-bersama-yang-lain, yang sebagai peristiwa dideterminasi oleh takdir (Geschick) bersama. $^{72}$ Gamblanglah kalau bagi Heidegger, historisitas (Geschichtlichkeit) terhubung erat dengan usaha mengejar takdir $(\text { Geschick })^{73}$ dalam semangat kebebasan untuk menyerahkan diri kepada kematian. ${ }^{74}$ Takdir diri mesti ditegaskan dan direalisasikan lewat historisitas Dasein yang terlibat, antara lain terlibat membangun takdir bangsa. Pemeliharaan bangsa berarti juga pemeliharaan atas takdir Dasein, yaitu identitasnya, dan yang berarti penegasan atas dirinya. Dengan demikian, Der Ursprung des Kunstwerkes tidak lain sebuah

\footnotetext{
71 Martin Heidegger, Ponderings II-VI: Black Notebooks 1931-1938, trans. Richard Rojcewicz, (Bloomington: Indiana University Press, 2016), 21. Edisi Jermannya, Überlegungen II-IV (Schwarze Hefte 1931-1938), hrsg. Peter Trawny (Frankfurt a.M: Vittorio Klostermann, 2014) 27.

${ }^{72}$ Heidegger, Being and Time, §74, 384.

${ }^{73}$ Pöggeler mencatat bahwa dalam hubungan dengan kampanya tentang 'final solution' atas orang-orang Yahudi, kata Geschick dimaknai sebagai "demonic skill". Lih. Pöggeler, "Heidegger's Political Self Understanding," 203.

${ }^{74}$ Heidegger, Being and Time, § 53, 266
} 
pernyataan terbuka mengenai dimensi politis dan identitas politik Dasein lewat karya seni. Jika ia menyatakan bahwa kebenaran menubuh dalam karya, maka bisa dikatakan bahwa kebenaran identitas dinyatakan secara paling tegas melalui setiap karya. Dengan kata lain, kebenaran identitas ditempa dan diinstitusionalkan melalui karya seni.

Tema-tema seperti muasal, penegasan diri, pertarungan, penyingkapan Sein, das Volk, negara ibarat tenunan benang yang membentuk motif politis teks tersebut. Dalam ungkapan Lacoue-Labarthe, berarti teks tersebut membentangkan ke hadapan setiap pembaca sebuah mitos asali yang 'menghasut' pembaca untuk mengidentifikasi identitas politisnya dengan mitos tersebut. Mitos dalam pengertian sebagai "kekuatan atau kekuasaan" [puissance] yakni kesatuan antara kekuatan fundamental dan orientasi individu atau masyarakat, sebuah kekuasaan dari dalam, bersifat konkret dan menubuh menjadi identitas.

75 Cf. Philippe Lacoue-Labarthe, Heidegger, Art and Politics: The Fiction of the Political, trans. Chris Turner (Oxford: Basil Blackwell, 1990) 93-94.

${ }^{76}$ Jacques Taminiaux, "The Origin of "The Origin of the Work of Art,", Reading Heidegger: Commemorations, ed. John Sallis (Bloomington:
Puissance ini dimaknai sebagai impian, sebagai proyeksi tentang suatu gambaran politis masa depan, dengannya seseorang diidentifikasi melalui sebuah komitmen yang total dan langsung. Ia mengandung model mengenai kemilau identitas dan karena itu harus direalisasikan lewat politik sebagai jalannya. ${ }^{75}$

Bahwa teks ini ditulis setelah periode "arus balik" (Kehre), tidak berarti terlepas dari impian Heidegger sebelumnya mengenai bangkitnya identitas Jerman yang terpuruk setelah kalah total dalam perang dunia pertama maupun kedua. $^{76}$ Maka, yang perlu diwaspadai dari teks ini, adalah kemungkinan mengembalikan pemaknaan Sein, dengan mengobjektivasinya sebagai Dasein, yakni menafsirkan Dasein sebagai Sein sekaligus mereduksi Sein hanya pada kelompok tertentu atau subjek tertentu. Inilah sebentuk romantisisme politik fiksional, di mana Dasein dipandang sebagai pencipta dan pemelihara, dan secara politis menjadi alasan pembenaran

Indiana University Press, 1993) 392. Cf. Heidegger, "The Self-Assertion of The German University," 2929; Cf. Zimmerman, Heidegger's Confrontation with Modernity, ch. 5; Cf. Emmanuel Faye, "Nazi Foundations in Heidegger's Work," South Central Review, Vol. 23, No. 1 (2006) 56. 
kekuasaan, ${ }^{77}$ lewatnya penguasa merasa dirinya sebagai penyelamat politis bagi rakyatnya. Kekuasaan adalah pertarungan untuk menegaskan diri sebagai pencipta dan pemelihara. Hal mana terjadi pada periode sebelumnya, ketika Heidegger mencoba mengartikulasi Sein ke dalam sosok pemimpin politis seperti Hitler.

Dalam konteks kontemporer, seni telah menjadi salah satu elemen utama bagi menguatnya industri hasrat yang diarahkan kepada perengkuhan kekuasaan. Apa yang disebut Heidegger bahwa seni telah dikeluarkan dari dirinya, terulang lagi dengan wajahnya yang baru. Seni menjadi otonom dari ritus-ritus, dikosongkan dari hubungannya subjek atau dengan kata lain seni menyingkirkan manusia sebagai subjek sekaligus sebagai jalan penegasian terhadap tuntutan moral yang menempatkan manusia sebagai tujuan dalam dirinya sendiri. ${ }^{78}$ Seni menjadi suaka pelepasan hasrat. Oleh teknologi dan kekuasaan, keindahan dilihat dengan referensi pada subjek

77 Satu ulasan penting tentang tema ini dapat dibaca pada Paul Budi Kleden, "Melahirkan dan Membesarkan Teroris: Führer dalam Filsafat Heidegger," Jurnal VOX (STFK Ledalero -Maumere), Seri 49, No.1 (2004) 11-30.

78 Cf. Roger Scruton, Beauty, (Oxford: Oxford University Press, 2009) 159; Cf. Axel Honneth, yakni persepsinya, aisthesis. Di sini, seni direduksi kepada estetika yang terskenariokan oleh teknologi, yang mendukung konsumsi yang berulangulang, yang dibangun atas dasar kepuasan imaginer dan simbolis dengan polesan artifisial sebagai karakter daya pertimbangan selera, perburuan kesenangan atau kenikmatan tanpa interese dan finalitas tanpa maksud yang jelas dengan tujuan mendukung kekuasaan tertentu. Di sini, seni yang berkaitan dengan peristiwa kebenaran menjadi peristiwa hasrat. Inilah alasannya Honneth menyatakan bahwa "seni adalah tempat utama patologipatologi sosial.",79

Bila kilau sebuah karya seni, puisi kalau menurut Heidegger, tidak lagi sebagai wilayah penampakkan kebenaran (aletheia), tetapi sebagai sebuah konstruksi hasrat dalam kultur kapitalisme, maka seni hanya akan menghantar kepada sebuah represi nonterbuka. Pengalaman subjektif

\footnotetext{
"Decentered Autonomy: The Subject after the Fall," The Fragmented World of the Social, ed. Charles W. Wrigth (Albany, NY: SUNY Press, 1995) 261-271.

79 Axel Honneth, "Philosophy in Germany," Wawancara oleh Simon Critchley dalam Radical Philosophy 89 (May/June 1998) 35.
} 
menutup jalan kepada pembicaraan atas hal-hal etis, yang sering dalam tingkatan tertentu, membutuhkan evidensi universal-konkret, kendati yang universal itu tidak pernah tuntas dirumuskan. Ketika ditempatkan dalam konteks politik, seni cenderung menjadi corong lewatnya lahir banyak pelanggaran, penyimpangan dan perpecahan dalam kehidupan konkret dan melahirkan beragam disrespek. Dalam jalur ini, lewat satu dan lain cara, seni atau lebih tepatnya estetika melahirkan patologi massa yang dengan gampang disubtitusikan pada sosok tertentu demi kepentingan politik. Dengan demikian, dalam budaya massa yang bersifat "chaosmotik" 80 setiap upaya pembebasan cenderung berbalik arah menjadi proses penundukan secara tak sadar.

Lebih dalam lagi, kita mengetahui bahwa sebuah pendirian yang cukup banyak diterima oleh pemikir kontemporer adalah menyingkirkan

${ }^{80}$ Cf. Felix Guattari, Chaosmosis: An Ethico-Aesthetic Paradigm, trans. Paul Bains and Julian Pefanis (Bloomington: Indiana University Press, 1995).

81 Lihat pernyataan Honneth berikut: “... social emancipation, and in that respect, I also strongly believe, against Rorty, that there is a task for philosophy today because there is no other place, and there is no other theoretical or intellectual medium which allows us, with a certain intention of universality, to reflect on systematic deficiencies of our pembicaraan mengenai kebenaran dan menggantikannya dengan sebentuk kompromi perasaan. Rasionalitas dianggap berkaitan dengan kepentingan dominasi, penundukkan, peringkusan terhadap "yang lain" atas nama kebenaran. Rasionalitas lalu berarti keseragaman. Rorty misalnya, mengkampanyekan bahwa dalam konteks kontemporer, hanya literatur saja yang memiliki hak mutlak memikirkan kemanusiaan. $^{81}$ Para filsuf harus dideprofesionalisasi posisi mereka dan diidentifikasi sebagai sastrawan. Ada yang menyatakan bahwa kalau seseorang berusaha menyatakan sebuah kebenaran, ia sebenarnya sedang berusaha menundukkan orang lain di bawah kekuasaannya. $^{82}$

Sikap relativis atau pragmatis gaya Rortyan misalnya, pada gilirannya mengambil bentuknya dengan memberi tempat bagi semua bentuk kehidupan untuk mendapatkan aktualitasnya dalam

own culture, our own society. I think is wrong to say, as Rorty does, that this is only a task for literature. It is clear that you can understand literature in such a way, as a kind of medium for violations, deficiencies and ruptures of our life." Honneth, "Philosophy in Germany," 38.

${ }^{82} \mathrm{Cf}$. Richard Wolin, The Seduction of Unreason: The Intellectual Romance with Fascism from Nietzsche to Postmodernism, (New Jersey: Princeton University Press, 2004) 21. 
kehidupan publik. Secara teoritis berarti, memberi tempat bagi semua bentuk perspektif yang berbeda untuk berkembang. Secara praktis berarti memberi tempat bagi setiap cara hidup yang berbeda-beda untuk tetap hidup di tengah pluralitas. Sikap ini secara ideal menjanjikan, namun dalam praktisnya, bila rasionalitas tidak digunakan lagi di hadapan keragaman, lalu apa yang akan kita gunakan bersama ketika dihadapkan dalam suatu problem masyarakat yang mengandung kontradiksi-kontradiksi internal, karena ketiadaan ukuran-ukuran etis yang diterima bersama. ${ }^{83}$ Bukankah kapasitas subjek untuk memeringkatkan nilai-nilai di antara beragam nilai yang dibentangkan di hadapannya, bergantung pada kemampuan refleksi yang merupakan tugas rasio diskursif?

\section{Kesimpulan}

Heidegger merefleksikan karya seni dalam hubungannya dengan Dasein dan Sein. Sebagaimana Hegel memikirkan seni dalam hubungan dengan sistem filsafatnya, yang mana seni hanyalah

${ }^{83}$ Cf. Franz Magnis-Suseno, Pijar-pijar Filsafat: Dari Gatholoco ke Filsafat Perempuan, dari Adam Müller momen transisi antara roh objektif dan roh absolute; hal yang sama terlihat dilakukan oleh Heidegger. Karya seni sekaligus merupakan momen dan tempat berlangsungnya kebenaran sebagai peristiwa, yakni peristiwa tersingkapnya Sein, terutama penyingkapan identitas bangsanya. Ini berarti, filsafat seni Heidegger adalah tempat Dasein terlibat dalam keseluruhan eksistensinya sebagai yang terlempar (Geworfenheit) di sana ( $D a$ ) demi merengkuh otentisitas dirinya. Momen otentisitas itu hanya bermakna jika disertai dengan sikap penegasan diri Dasein.

Bagi Heidegger, karya seni sedapat mungkin menjadi suatu karya yang berkaitan dengan historisitas dan identitas Dasein. Karya seni tidak hanya sebatas sebuah objek kesenangan subjektif, yang melulu diletakkan pada subjektivitas individu sebagai referensi. Maka, di akhir teks tersebut, artikulasi karya seni tidak lagi pada historistas dan kebenaran tentang Dasein yang individual, tetapi menyangkut historisitas, pemuasalan kebenaran tentang identitas Jerman. Ia beralih dari

ke Postmodernisme, (Yogyakarta: Kanisius, 2005) 231233. 
Dasein kepada Volksein. Jadi artikulasi seni ditempatkan dalam konteks politik. ${ }^{84}$ Seni harus kontekstual dalam arti mampu menghantar setiap orang untuk mengalami kebenaran tentang Sein yang hadir lewat historisitas Dasein dan yang memuncak dalam identitas Volksein. Dengan begini, pada Heidegger gamblang terlibat bahwa pada tingkat tertentu kebenaran estetis mencerminkan kebenaran identitas politik.

Maka, yang perlu diwaspadai dari teks ini adalah sebentuk rormantisisme politik, penegasan identitas yang akan cenderung menolak yang tidak seidentitas dengan sang pembuat pernyataan, bahaya reduksi seni pada partikularitas identitas tertentu. Karya seni dapat menjadi bersifat propagandis. Dalam konteks kontemporer, seni sebagai objek estetis, gampang menjadi sarana akumulasi kekuatan, dengan cara merayu

\footnotetext{
${ }^{84}$ Heidegger, "The Origin of the Work of Art," 50.

${ }^{85}$ Cf. Wolin, The Seduction of Unreason, 205.

${ }^{86}$ Di sini, saya mengikuti interpretasi Agamben atas proper dan improper Heidegger tidak dalam pengertian autentisitas dan inautentisitas, tetapi dalam pengertian pantas/tidak pantas atau seharusnya/tidak seharusnya. Giorgio Agamben, Stanzas: Word and Phantasm in Western Culture, trans. Ronald L. Martinez (Minneapolis: University of Minnesota Press, 1993) ch. 18.
}

tanpa pihak yang dirayu atau dibujuk menyadari ke mana kekuasaan politik itu diarahkan. ${ }^{85}$ Dengan kata lain, karya seni menjadi sebentuk estetisasi ketidaksadaran. Bukan lagi Sein yang mewahyukan dirinya, tetapi hasrat (desire) yang memiliki Dasein; Dasein yang tidak lagi mengarahkan diri berdasarkan ketekadan, keputusan dan proyeksi, tetapi Dasein yang sepenuhnya diarahkan oleh hasrat mencaplok yang tak habis-habisnya. Gagasan Heidegger mengenai seni dapat menjadi salah satu jalan kita merefleksikan kembali apa yang seharusnya (proper) dan apa yang tidak seharusnya (improper), dalam hubungan yang tak terpisahkan dari Dasein yang memutuskan. ${ }^{86}$ Dalam perspektif etikopolitik, seni dalam hal ini yang estetis sedapatnya dilintasi terusmenerus. 


\section{Daftar referensi}

Agamben, Giorgio. Stanzas: Word and Phantasm in Western Culture. Trans. Ronald L. Martinez. Minneapolis: University of Minnesota Press, 1993.

Biemel, Walter. Martin Heidegger: An Illustrated Study. Trans. J. L. Mehta. New York: Harcourt Brace Jovanovich, 1976.

da Silva Gusmão, Martinho G. HansGeorg Gadamer: Penggagas Filsafat Hermeneutik Modern yang Mengagungkan Tradisi. Yogyakarta: Kanisius, 2012.

Faye, Emmanuel. "Nazi Foundations in Heidegger's Work." South Central Review, 23, No. 1 (Spring 2006) 55-66.

http://www.jstor.org/stable/400399 13 (acces 22.04.2014).

Ferris, David. "Politics of the Useless: The Work of Art in Benjamin and Heidegger." Sparks Will Fly: Benjamin and Heidegger. Eds. Andrew Benjamin and Dimitris Vardoulakis. Albany, NY: SUNY Press, 2015.

Gadamer, Hans-Georg. Truth and Method. Second revised edition. Trans. Joel Weinsheimer and Donald G. Marshall. London: Continuum, 2004.

Gaston, Sean. Derrida and Disinterest. London: Continuum, 2005.

Guattari, Felix. Chaosmosis: An EthicoAesthetic Paradigm. Trans. Paul Bains and Julian Pefanis. Bloomington: Indiana University Press, 1995.

Hammermeister, Kai. The German Aesthetic Tradition. Cambridge: Cambridge University Press, 2002.
Harries, Karsten. Art Matters: A Critical Commentary on Heidegger's "The Origin of the Work of Art". New York: Springer, 2009.

Heidegger, Martin, Hoseki Shin'ichi Hisamatsu, et al., "Art and Thinking: Protocol of a Colloquium on May 18, 1958." Trans. Carolyn Culbertson and Tobias Keiling. Philosophy Today, Vol 61, Iss 1 (Winter 2017): 47-51. [doi:

10.5840/philtoday2017317146].

Heidegger, Martin. "Der Ursprung des Kunstwerkes." Holzwege. Hrsg. v. Friedrich-Wilhelm von Herrmann. Frankfurt am Main: Vittorio Klostermann, 2003 [1977].

----------. "Five Statements of Art." Nietzsche Vol. I-II. Trans. David Farrell Krell. New York: HarpersCollins, 1991.

----------------. "Letter on Humanism." Pathmark. Trans. Frank A. Capuzzi. Cambridge: Cambridge University Press, 1998.

Being." Pathmarks. Trans. William McNeill. Cambridge: Cambridge University Press, 1998.

" "Six Basic Developments in the History of Aesthetics." Nietzsche Vol. I-II. Trans. David Farrell Krell. New York: HarpersCollins, 1991.

-------------. "The End of Philosophy and the Task of Thinking." Basic Writings: From Being and Time (1927) to the Task of Thinking (1964). Ed. David Farrell Krell. New York: Harper Collins Publishers, 1993.

Poetry, Language, Thought. Trans. 
Albert Hofstadter. New York: Harper \& Row, 2001.

--------------. "The Self-Assertion of the German University." The Heidegger Controversy: A Critical Reader. Third edition. Ed. Richard Wolin. Cambridge, MA: The MIT Press, 1998

Art" Off the Julian Young and Kenneth Haynes. Cambridge: Cambridge University Press, 2002.

--------.. "The Way to Language." Martin Heidegger. Basic Writings: From Being and Time (1927) to the Task of Thinking (1964). Ed. David Farrell Krell. New York: Harper Collins Publishers, 1993.

John Macquarrie and Edward Robinson. Oxford: Blackwell, 1978.

-------------. Hegel. Trans. Joseph Arel
and Niels Feuerhahn. Bloomington: Indiana University Press, 2015.

Hölderlin's Hymns Germania and the Rhine. Trans. William McNeill and Julia Ireland. Bloomington: Indiana University Press, 2014.

---------. On the Way to Language. Trans. Peter D. Hertz. New York: HarperOne, 1982.

---------------. Ponderings II-VI: Black Notebooks 1931-1938. Trans. Richard Rojcewicz. Bloomington: Indiana University Press, 2016. Ponderings XII-XV: Black Notebooks 1939-1941. Trans. Richard Rojcewicz. Bloomington: Indiana University Press, 2017.

Hölderlin's Poetry. Trans. Keith
Hoeller. New York: Humanity Books, 2000.

--------------. The Essence of Truth: On

Plato Parable of the Cave and the Theaetetus. Trans. Ted Sadler. London: Continuum, 1994.

\section{Überlegungen II-IV}

(Schwarze Hefte 1931-1938). Hrsg.

Peter Trawny. Frankfurt a.M:

Vittorio Klostermann, 2014.

--------------.. Überlegungen, XII-XV

(Schwarze Hefte 1939-1941). Hrsg.

Peter Trawny. Frankfurt a.M:

Vittorio Klostermann, 2014.

Honneth, Axel. "Decentered Autonomy:

The Subject after the Fall." The Fragmented World of the Social. Ed. Charles W. Wrigth. Albany, NY: SUNY Press, 1995.

--------. "Philosophy in Germany."

Interviewed by Simon Critchley. Radical Philosophy 89 (May/June 1998) 27-39.

Kleden, Ignas. Sikap Ilmiah dan Kritik Kebudayaan. Jakarta: LP3ES, 1987.

Kleden, Paul Budi. "Melahirkan dan Membesarkan Teroris: Führer dalam Filsafat Heidegger." Jurnal Filsafat Vox 49, No.1 (2004) 11-30. . "Memasang Punggung ke Masa Depan - Menyisir Jejak Masa Lampau: Menyimak Filsafat Sejarah Walter Benjamin.” Mengabdi Kebenaran. Eds. Frans Ceunfin dan Felix Baghi. Maumere: Ledalero, 2005.

Kockelmans, Joseph J. Heidegger on Art and Art Work. Dordrecht: Martinus Nijhoff Publishers, 1986.

Lacoue-Labarthe, Philippe. Heidegger, Art and Politics: The Fiction of the Political. Trans. Chris Turner. Oxford: Basil Blackwell, 1990. 
Long, Christopher P. “Art's Fateful Hour: Benjamin, Heidegger, Art and Politics." New Source German Critique, No. 83, Special Issue on Walter Benjamin, (Spring Summer, 2001) 89-115. http://www.jstor.org/stable/827790 (acces 03.08.2015).

Magnis-Suseno, Franz. Pijar-pijar Filsafat. Dari Gatholoco ke Filsafat Perempuan, dari Adam Müller ke Postmodernisme. Yogyakarta: Kanisius, 2005.

Marx, Karl. "The Eighteenth Brumaire of Louis Bonaparte." Karl Marx Selected Writings. Ed. David McLellan. Oxford: Oxford University Press, 2000.

Pöggeler, Otto. "Heidegger's Political Self-understanding." The Heidegger Controversy: A Critical Reader. Ed. Richard Wolin. Cambridge: MIT Press, 1998.

-----------. Martin Heidegger's Path of Thinking. Trans. Daniel Magurshak and Sigmund Barber. New York: Humanities Press International Inc., 1987.

Richardson, William J. Heidegger: Through Phenomenology to Thought. Fourth edition. New York: Fordham University Press, 2003.

Taminiaux, Jacques. "The Origin of "The Origin of the Work of Art."” Reading Heidegger: Commemorations. Ed. John Sallis. Bloomington: Indiana University Press, 1993.

Wolin, Richard. The Seduction of Unreason: The Intellectual Romance with Fascism from Nietzsche to Postmodernism. New Jersey: Princeton University Press, 2004.
Zimmerman, Michael E. Heidegger's Confrontation with Modernity: Technology, Politics and Art. Bloomington: Indiana University Press, 1990. 
LUMEN VERITATIS: Jurnal Filsafat dan Teologi, Volume. 12, Nomor 1, Oktober 2019 pSSN 1978-3469; eISSN 2657-1927 